\title{
MEDICINAL PROPERTIES OF A GARDEN PLANT STROBILANTHES HAMILTONIANA (STEUD.) BOSSER AND HEINE
}

\author{
ALBY ALPHONS BABY ${ }^{1 *}$, REGI RAPHAEL $\mathrm{K}^{2}$ \\ ${ }^{1}$ Research and Development Centre, Bharathiar University, Coimbatore, Tamil Nadu, India. ${ }^{2}$ Department of Botany, St. Mary's College, \\ Thrissur, Kerala, India. Email: albyalphons@gmail.com
}

Received: 18 May 2018, Revised and Accepted: 09 July 2018

\section{ABSTRACT}

Objectives: Strobilanthes hamiltoniana (Steud.) Bosser and Heine (Acanthaceae) is commonly used in the traditional systems of medicine against helminthiasis and spider bite poison. The plant is known as a garden plant, and medicinal properties of this plant are not yet reported.

The present study gives a first insight of antimicrobial, anthelmintic, and antioxidant properties of S. hamiltoniana leaves.

Methods: All the analysis was done according to standard protocols.

Results: The ethanol extract of $S$. hamiltoniana produced significant antibacterial, antifungal, and anthelmintic properties in a dose-dependent manner, which analyses its folk claim.

Conclusion: This paper first reporting the medicinal properties of $S$. hamiltoniana leaves and the further procedures of identification and isolation of active principles is in progress.

Keywords: S. hamiltoniana, Antimicrobial, Anthelmintic, Antioxidant, Traditional medicine.

(C) 2018 The Authors. Published by Innovare Academic Sciences Pvt Ltd. This is an open access article under the CC BY license (http://creativecommons. org/licenses/by/4. 0/) DOI: http://dx.doi.org/10.22159/ajpcr.2018.v11i11.20081

\section{INTRODUCTION}

The reports on the use of plant drugs for primary health care go back to time immemorial. Together with the evolution of scientific and social progress, the knowledge of drug has also developed [1]. Throughout the history, plants had their place in healing. Primitive man had used plants as prophylactic and therapeutic aids to health. The data acquired largely on a trial and error basis, have led to the development of many useful medicinal agents

After the method of "modern science" emerged in Europe, the entire gamut of traditional knowledge being re-examined, re-evaluated, and reformed in the light of experimental verification, and scientific theorizing. Hence, the way through which their modern knowledge superstructure was the result of the development based on their traditional knowledge. However, in the case of India, modern science and technology were introduced here by the colonial rulers, and it was presented and accepted as a symbol of their superiority. It did not grow up from the foundations of indigenous knowledge. On the contrary, it was introduced through negation of all existing knowledge as unscientific or primitive and hence worthless. Our tragedy was that we considered all the traditional knowledge as worthless, and learned modern science and technology transplanted from the west as the only valid system of knowledge. As a result, much of our traditional knowledge was lost or forgotten [2].

Today, many of the medicines are based on herbal remedies used by native people. Although the percentage of plant species used for this purpose is small, the potential for finding new drug is great. The herbal remedies are nontoxic and have no side effects as per their practice. The searching of new pharmaceutical drugs from ethnomedicinal plant is a shortcut in the drug discovery process. The rate of success in the production of new drugs from randomly synthesized chemicals is only 1 in 10,000. However, it is 1 in 125 in the case of drug searched from medicinal plants [3].
Strobilanthes hamiltoniana is a member of the family Acanthaceae. It is a shrub of about $1 \mathrm{~m}$ height with erect quadrangular branches. Leaves are opposite, subequal, ovate or elliptic, and narrowed at base. Flowers in large open panicles, often much branched and peduncles usually slender. Calyx is deeply 5-lobed, lobes equal, or sub-equal with a midvein. Corolla is tubular, pale purple colored, glabrous outside, and hairy inside. Stamens 4 and didynamous. Anther lobes are small and dorsifixed. Ovary is located on a small disc, style slightly exerted, slightly broadened at the apex, and finely pubescent.

S. hamiltoniana is known as a beautiful garden plant. The medicinal properties of this plant are not well noticed. The traditional healers using this plant against helminthiasis and in poison treatment. Therefore, the present study was conducted to evaluate its biological properties and thereby confirm its traditional use.

\section{METHODS}

Collection and identification of plant materials

The plant $S$. hamiltoniana was collected from Mannamangalam, Thrissur District of Kerala, India. Taxonomic identification made with Flora of Presidency of Madras by Gamble [4].

\section{Preparation of extracts}

Leaves of the plant were shade dried for several days. The dried plant material was ground to a coarse powder using mixer grinder, and $50 \mathrm{~g}$ of the powdered plant materials were soaked in 95\% methanol (1:5) for $72 \mathrm{~h}$ [5]. The solvent removed by rotary evaporation and dried extract was stored in the refrigerator for further studies.

\section{Anthelmintic property}

The standard albendazole $(25 \mathrm{mg} / \mathrm{mL})$ and the test solutions of $S$. hamiltoniana $(25,50$, and $100 \mathrm{mg} / \mathrm{mL})$ were evaluated for anthelmintic activity using Indian adult earthworm Pheretima posthuma. Identified worms were collected from Kerala Agricultural 
Table 1: Anthelmintic property of $S$. hamiltoniana leaves

\begin{tabular}{l|lllll}
\hline Observation & Distilled water & Albendazole $\mathbf{( 2 5} \mathbf{~ m g} / \mathbf{m L})$ & Drug (25 $\mathbf{~ m g} / \mathbf{m L})$ & Drug (50 $\mathbf{~ m g} / \mathbf{m L})$ & Drug (100 $\mathbf{~ m g} / \mathbf{m L})$ \\
\hline Time taken for paralysis (min) & - & $25 \pm 3$ & $40.3 \pm 1.53$ & $30.6 \pm 0.57$ & $23.7 \pm 1.53$ \\
Time taken for death (min) & - & - & $75.3 \pm 1.53$ & $58 \pm 1$ & $50.3 \pm 0.57$ \\
\hline
\end{tabular}

S. hamiltoniana: Strobilanthes hamiltoniana

Table 2: Antioxidant property of $S$. hamiltoniana leaves

\begin{tabular}{|c|c|c|}
\hline \multirow{2}{*}{$\begin{array}{l}\text { Concentration of plant extract } \\
\left(\mu \mathrm{gL}^{-1}\right)\end{array}$} & \multicolumn{2}{|c|}{ Percentage of inhibition } \\
\hline & DPPH & NBT \\
\hline 10 & $3.5 \pm 0.5$ & $3.4 \pm 0.69$ \\
\hline 15 & $8 \pm 1.6$ & $13.5 \pm 1.80$ \\
\hline 25 & $15.8 \pm 0.76$ & $19.7 \pm 2.4$ \\
\hline 50 & $22.43 \pm 2.91$ & $26.5 \pm 1.06$ \\
\hline 75 & $30 \pm 0.9$ & $30.9 \pm 0.47$ \\
\hline 100 & $38.65 \pm 1.38$ & $36.27 \pm 2.2$ \\
\hline 250 & $74.8 \pm 3.5$ & $41.6 \pm 0.41$ \\
\hline 500 & $80.25 \pm 1.08$ & $51.2 \pm 0.28$ \\
\hline 750 & $83.16 \pm 1.20$ & $58.94 \pm 1.08$ \\
\hline 1000 & $87.48 \pm 2.2$ & $70.73 \pm 1.02$ \\
\hline IC50 value & $148.3 \pm 7.6$ & $496.6 \pm 15.4$ \\
\hline
\end{tabular}

S. hamiltoniana: Strobilanthes hamiltoniana

Table 3: Antibacterial property of $S$. hamiltoniana leaves

\begin{tabular}{lllll}
\hline Organism & \multicolumn{3}{l}{ Zone of inhibition (mm) } & \\
\cline { 2 - 5 } & $\begin{array}{l}\text { Chloramphenicol } \\
(\mathbf{2 5} \boldsymbol{\mu g})\end{array}$ & $\mathbf{1 0 0} \boldsymbol{\mu g}$ & $\mathbf{2 5 0} \boldsymbol{\mu g}$ & $\mathbf{5 0 0} \boldsymbol{\mu g}$ \\
& & & \\
\hline K. pneumoniae & $21.6 \pm 1.15$ & $10.6 \pm 0.57$ & $12.3 \pm 0.57$ & $16.6 \pm 1.15$ \\
S. typhi & $26.3 \pm 0.57$ & $12.3 \pm 0.57$ & $16 \pm 1$ & $18.3 \pm 0.57$ \\
P. aeruginosa & $9 \pm 0.28$ & $6.3 \pm 0.57$ & $8.3 \pm 0.57$ & $9.3 \pm 0.57$ \\
B. cereus & $16.5 \pm 0.76$ & $7.3 \pm 0.57$ & $9.6 \pm 0.57$ & $11 \pm 1$ \\
S. pyogenes & $15.6 \pm 1.52$ & $7.3 \pm 0.57$ & 8 & $10.3 \pm 0.57$ \\
S. aureus & $21.3 \pm 0.57$ & $6.6 \pm 1.15$ & $9 \pm 1$ & $11 \pm 1$ \\
\hline
\end{tabular}

S. aureus: Staphylococcus aureus, B. cereus: Bacillus cereus, $S$. pyogenes:

Streptococcus pyogenes, K. pneumonia: Klebsiella pneumonia,

P. aeruginosa: Pseudomonas aeruginosa, S. typhi: Salmonella typhi,

S. hamiltoniana: Strobilanthes hamiltoniana

Table 4: Antifungal property of $S$. hamiltoniana leaves

\begin{tabular}{|c|c|c|c|c|}
\hline \multirow[t]{2}{*}{ Organism } & \multicolumn{4}{|c|}{ Zone of inhibition (mm) } \\
\hline & $\begin{array}{l}\text { Fluconazole } \\
(15 \mu \mathrm{g})\end{array}$ & $100 \mu \mathrm{g}$ & $250 \mu \mathrm{g}$ & $500 \mu \mathrm{g}$ \\
\hline A. niger & $15.3 \pm 0.57$ & $20.6 \pm 0.57$ & $22.6 \pm 0.57$ & $26.3 \pm 1.53$ \\
\hline A. flavus & $13.7 \pm 1.15$ & $17.3 \pm 0.57$ & $20.3 \pm 1.15$ & $22.3 \pm 0.57$ \\
\hline P. notatum & $13.3 \pm 0.57$ & $14 \pm 1$ & $15.3 \pm 0.57$ & $18.3 \pm 0.57$ \\
\hline C. albicans & $\mathrm{R}$ & $16.3 \pm 0.57$ & $19.3 \pm 0.58$ & $21 \pm 1$ \\
\hline
\end{tabular}

Candida albicans, Aspergillus niger, Aspergillus flavus, Penicillium notatum,

S. hamiltoniana: Strobilanthes hamiltoniana

University, Mannuthy, Kerala. Observations made for the time taken for paralysis and death of individual worms. According to the procedure of Braca et al., the experiment time was fixed as 4 hours [6]. When the worms are not showing any signs of movements, the paralysis was confirmed and noted the time taken for paralysis. To confirm the death, the worms shaken vigorously and dipped in hot water of up to $50^{\circ} \mathrm{C}$ [7].

\section{Antioxidant property screening}

1, 1-diphenyl-2-picrylhydrazyl (DPPH) free radical scavenging assay

Oxygen is vital for most living organisms; it also acts as a source of endogenic oxidants. Free radical, the unpaired electron in the outer orbit is harmful because in searching for a pairing electron it takes an electron from a stable molecule and resulting in a chain of reactions that can injure the tissue [8]. The best method to screen the free radical scavenging activity of the plant extract was based on the radical scavenging effect of the compound DPPH - by a method given by Braca et al. [9]. The test extracts of different concentrations and $6.34 \mu \mathrm{M}$ solution of DPPH were prepared in methanol. $100 \mu \mathrm{L}$ test solution along with $100 \mu \mathrm{L}$ DPPH solution and $800 \mu \mathrm{L}$ of methanol were taken in a test tube and after proper mixing kept in the dark for $20 \mathrm{~min}$. Optical density was measured using Cecil-Elect Spectrophotometer at $517 \mathrm{~nm}$. Control tube was set with $900 \mu \mathrm{L}$ methanol and $100 \mu \mathrm{L} \mathrm{DPPH}$ solution at $6.34 \mu \mathrm{M}$ concentration. Methanol used as blank and the optical density was recorded[10]. The formula for the calculation of the optical density is: [10].

Percentage $(\%)$ of inhibition $=\mathrm{A}-\mathrm{B} / \mathrm{A} \times 100$

Where $\mathrm{A}=$ Optical density of the control and $\mathrm{B}=$ Optical density of the sample.

\section{Superoxide radical scavenging activity}

In vitro superoxide radical scavenging activity was measured using riboflavin/nitro blue tetrazolium (NBT) reduction method. This method based on the generation of superoxide anions by auto-oxidation of riboflavin in the presence of light. The superoxides reduce NBT to a colored formazan that can be measured at $590 \mathrm{~nm}$. The capacity of extracts to inhibit the color to $50 \%$ is measured in terms of IC50 [10].

\section{Antimicrobial property screening}

Organisms and culture media

The pathogenic strains of bacteria and fungus obtained from the laboratory, Department of Microbiology, St. Mary's College, Thrissur, Kerala. Organisms used were Staphylococcus aureus, Bacillus cereus, Streptococcus pyogenes, Klebsiella pneumoniae, Pseudomonas aeruginosa, Salmonella typhi, Candida albicans, Aspergillus niger, Aspergillus flavus, and Penicillium notatum. For maintaining the bacterial cultures, nutrient agar (NA) was used, while for fungal cultures Sabouraud dextrose agar (SDA) was used.

\section{Antibacterial and antifungal activity of the plant extract}

Well-diffusion assay method was used to determine the antimicrobial property [11]. Nutrient broth (NB) inoculated with bacteria and Sabouraud dextrose broth (SDB) inoculated with fungus were incubated at $37^{\circ} \mathrm{C}$ for $6 \mathrm{~h}$. The turbidity in the resulting suspensions was diluted with NB and SDB to obtain a transmittance of $74.3 \%$ (absorbance of 0.132 ) at $600 \mathrm{~nm}$. According to McFarland turbidity standards, this level of turbidity is equivalent to approximately $1.5 \times 10^{8} \mathrm{CFU} / \mathrm{mL}$ [12]. These cultures then inoculated on the surface of NA plates for bacteria toxicity screening and SDA for fungitoxicity screening. Using sterile cork borer, wells of $6 \mathrm{~mm}$ diameter were prepared on agar plates, and $50 \mu \mathrm{L}$ of sample at different concentrations $(100 \mu \mathrm{g} / \mathrm{mL}, 250 \mu \mathrm{g} / \mathrm{mL}$, and $500 \mu \mathrm{g} / \mathrm{mL}$ ) was loaded in each well. Antibiotics used as positive control (for bacteria - chloramphenicol; for fungus - fluconazole). The plates were incubated at $37^{\circ} \mathrm{C}$ for $24 \mathrm{~h}$, and the tests were carried out in triplicates. Zones of growth inhibition were measured using a transparent ruler, and clearing zones $>6 \mathrm{~mm}$ were considered susceptible to the extracts.

\section{RESULTS}

\section{Anthelmintic property of $S$. hamiltoniana leaves}

It was seen that the ethanolic extract of $S$. hamiltoniana leaves possesses dose-dependent antihelmintic activity when compared to a standard drug albendazole. The mean paralyzing time of P. posthuma with the 
dose of 25,50 , and $100 \mathrm{mg} / \mathrm{mL}$ was found to be $40.3 \pm 1.53,30.6 \pm 0.57$, and $23.7 \pm 1.53 \mathrm{~min}$, respectively. The mean death time of $P$. posthuma with the dose of 25,50 , and $100 \mathrm{mg} / \mathrm{mL}$ plant extract was found to be $75.3 \pm 1.53,58 \pm 1$, and $50.3 \pm 0.57 \mathrm{~min}$, respectively. In the case of albendazole at a dose of $25 \mathrm{mg} / \mathrm{mL}$ cause paralysis only, no death was observed during the experimental period of $4 \mathrm{~h}$ (Table 1). The result of our study proved it as an anthelmintic agent and thereby confirmed its traditional application.

\section{Antioxidant property screening of $S$. hamiloniana leaves}

The action of antioxidant compounds may be as free radical scavengers, reducing agents, initiator of the complexes of pro-oxidant metals and quenchers in singlet oxygen formation [13]. In recent years, many researchers focused on the search for natural antioxidants from medicinal plants [14].

\section{DPPH radical scavenging assay}

DPPH is a stable free radical at room temperature often used to evaluate the antioxidant activity of several natural compounds. The reduction capacity of DPPH radicals was determined by the decrease in its absorbance at $517 \mathrm{~nm}$, which is induced by antioxidants. The percentage of DPPH radical scavenging activity of ethanolic extract of S. hamiltoniana presented in Table 2. The plant drug exhibited a maximum DPPH scavenging activity of $87 \% \pm$ at $1000 \mu \mathrm{g} / \mathrm{mL}$ concentration with IC50 value of $148.3 \pm 7.6 \mu \mathrm{g} / \mathrm{mL}$

\section{Superoxide radical scavenging assay}

The superoxide radical scavenging assay also shows significant radical scavenging with IC50 value $496.6 \pm 15.4$. The activity was increasing with the increasing concentrations of the test solution and shows $71 \%$ of inhibition at $1000 \mu \mathrm{g} / \mathrm{mL}$ concentration (Table 2).

\section{Antimicrobial property of $S$. hamiltoniana leaves}

The present study reveals that the leaves of $S$. hamiltoniana had prominent antimicrobial activity against the human pathogenic bacteria and fungi studied (Tables 3 and 4). It was highly effective against the bacterial species $S$. typhi with a zone of growth inhibition of $18.3 \pm$ $0.57 \mathrm{~mm}$ at $500 \mu \mathrm{g} / \mathrm{mL}$ concentration, and it was least active against P. aeruginosa with $9.3 \pm 0.57 \mathrm{~mm}$ zone of growth inhibition at the same concentration. In case of antifungal screening, the highest activity was noted in case of $A$. niger with a zone of inhibition of $26.3 \pm 1.53 \mathrm{~mm}$ in the concentration $500 \mu \mathrm{g} / \mathrm{mL}$ and least activity in case of $P$. notatum with $18.3 \pm 0.57 \mathrm{~mm}$ zone of clearing in the same concentration. C. albicans was resistant to fluconazole, but it showed promising activity with the plant drug extract $(21 \pm 1 \mathrm{~mm}$ zone of inhibition at $500 \mu \mathrm{g} / \mathrm{mL}$ concentration).

\section{DISCUSSION}

Expectancy and quality of human life have increased tremendously during the past 50 years due to improvements in nutrition and use of antibiotics against infectious disease conditions. However, recent studies report that common bacterial populations in the gastrointestinal tracts of human beings such as lactic acid bacteria and bifidobacteria can act as a reservoir of antibiotic-resistant genes. From them, this resistance can be transferred to pathogenic bacteria through food chain or conjugation, which hampering the treatments of infections, i.e., indiscriminate use of synthetic antibiotics resulting in the development of multidrug-resistant pathogenic bacteria [15]. The use of broad-spectrum antibiotics instead of narrow spectrum once and consumption of antibiotics without expert prescription also leads to multidrug resistance.

The emergence of multidrug-resistant pathogenic bacteria and the adverse side effects due to the frequent use of synthetic drugs highlights the need for safe alternatives; this paves the way to traditional medicinal plants. The plant extracts are potential sources of new compounds which may be developed as effective drugs against microorganisms.
Further, the use of this plant may offer a new source of an antifungal agent against the pathogenic fungus such as C. albicans, A. niger, A. flavus, and $P$. notatum all these fungal species were inhibited by the crude drug in dose-dependent manner. In the lower concentration itself $(100 \mu \mathrm{g} / \mathrm{mL})$ C. albicans, A. niger, A. flavus, and P. notatum showed 16.3 $\pm 0.57,20.6 \pm 0.57,17.3 \pm 0.57$, and $14 \pm 1 \mathrm{~mm}$ of growth inhibition, respectively. C. albicans is not easily inhibited by other drugs.

\section{CONCLUSIONS}

According to the present study, the crude extract of $S$. hamiltoniana leaves possesses prominent antimicrobial, anthelmintic, and antioxidant properties, which analyses its folk claim. The presence of the biologically active secondary metabolites is the reason behind its bioactivity. Therefore, there is no doubt that this plant can definitely act as a reservoir of potentially useful chemical compounds which serve as drugs, provide newer leads, and clues for modern drug design.

\section{AUTHOR'S CONTRIBUTION}

Alby Alphons Baby has performed all the experiments in the laboratory. Regi Rahael K has provided the design, intellectual content to choose the plant and acts as a mentor for the works.

\section{CONFLICTS OF INTEREST}

The authors are declaring that there are no conflicts of interest regarding the publication of this article.

\section{REFERENCES}

1. de Pasquale A. Pharmacognosy: The oldest modern science. J Ethnopharmacol 1984;11:1-6.

2. Menon RV. Validating Traditional Knowledge. Compendium Traditional Knowledge. $26^{\text {th }}$ Kerala Science Congress; 2014. p. 76-9.

3. Chadwick DJ, Marsh J. Ethnobotany and the Search for New Drugs, Ciba Foundation Symposium 185. New York: John Wiley and Sons; 2007. p. 61-9.

4. Gamble JS. Flora of Presidency of Madras. Calcutta: Aldard and Son Publishing Company Ltd.; 2004.

5. Taleb-Contini SH, Salvador MJ, Balanco JM, Albuquerque S, De Oliveria DC. Antiprotozoal effect of crude extracts and flavonoids isolated from Chromolaena hirsute (Asteraceae). Phyto Res 2004;18 Suppl 3:250-4.

6. Baby AA, Raphael KR. Potential antimicrobial, anthelmintic and antioxidant properties of Areca catechu L root. Int J Pharm Pharm Sci 2014;6 Suppl 6:486-9.

7. Baby AA, Raphael KR. First step towards unravelling the medicinal properties of an endemic traditional medicine Bauhinia phoenicea wight \& arn. bark. Int J Pharm Pharm Sci 2015;7 Supp1 9:403-5.

8. Shivanandham V. Free radicals in health and diseases a mini review. Newsletter 2011;1:1062-77.

9. Braca A, Sortino C, Politi M, Morelli I, Mendez J. Antioxidant activity of flavonoids from Licania licaniaeflora. J Ethnopharmacol 2002;79:379-81.

10. Bors W, Saran M, Elstner EF. Screening for plant anti-oxidants. In: Linskens HF, Jackson JF, editors. Modern Methods of Plant AnalysisPlant Toxin Analysis- New Series. Berlin: Springer; 1992. p. 277-95.

11. du Toit EA, Rautenbach M. A sensitive standardised micro-gel well diffusion assay for the determination of antimicrobial activity. J Microbiol Methods 2000;42:159-65.

12. Rojas JJ, Ochoa VJ, Ocampo SA, Muñoz JF. Screening for antimicrobial activity of ten medicinal plants used in Colombian folkloric medicine: A possible alternative in the treatment of non-nosocomial infections. BMC Complement Altern Med 2006;6:2

13. Andlauer W, Furst P. Antioxidative power of phytochemicals with special reference to cereals. Cereal Foods World 1998;43:356-9.

14. Jayaprakasha GK, Selvi T, Sakariah KK. Antibacterial and antioxidant activities of grape (Vitisvinifera) seed extract. Food Res Int 2003;36:117-22.

15. Ammor MS, Flórez AB, Mayo B. Antibiotic resistance in nonenterococcal lactic acid bacteria and bifidobacteria. Food Microbiol 2007;24:559-70 